\title{
Optimizing the amount of pig manure in the vermicomposting of spent mushroom (Lentinula) substrate
}

\author{
Yajing Shi ${ }^{\text {Equal first author, } 1}$, zhen yu Wang ${ }^{\text {Corresp., Equal first author, } 1 \text {, Yurong Wang }}{ }^{1}$ \\ ${ }^{1}$ School of Biological and Chemical Engineering, Liaoning Institute of Science and Technology, Benxi, Liaoning, China \\ Corresponding Author: zhen yu Wang \\ Email address: wzy150618@sina.com
}

Background. The mushroom industry produces a large amount of spent mushroom substrate (SMS), which requires a large geographical footprint and causes pollution.

Methods. We sought to optimize the $\mathrm{C}: \mathrm{N}$ ratio of the initial feedstock used in vermicomposting of SMS by adding pig manure additions. We applied five treatments to the initial feedstock (S0, S1, S2, S3, and S4) with different C:N ratio of approximately 35, $30,25,20$, and 15 , respectively. Results. Our results showed that lignin and cellulose in SMS were degraded after 56 days vermicomposting, especially in S2 (77.05\% and $45.29 \%$, respectively) and S3 (65.05\% and $48.37 \%$, respectively) treatments. We observed the degradation of the fibrous structure in SMS using pig manure treatments after vermicomposting by microscope and scanning electron microscope. Cellulase and polyphenol oxidase (PPO) were enhanced in pig manure treatments during vermicomposting, especially in the S2 and S3 treatments. The biomass of earthworms in the S2 treatments was at its highest level among all treatments at 28 to 56 days. The high level of PPO activity in the S2 treatment may protect cellulase and earthworms against the aromatic toxicity that is a byproduct of lignin degradation, particularly at 28 to 56 days of vermicomposting. Conclusively, it indicated that the $\mathrm{C} / \mathrm{N}$ ratio of 25 in the $\mathrm{S} 2$ treatment was the optimal for SMS vermicomposting with the addition of pig manure. Our results provide a positive application for the recycling of both SMS and pig manure. 


\section{Optimizing the amount of pig manure in the}

\section{2 vermicomposting of spent mushroom (Lentinula)}

3 substrate

4 Yajing Shi ${ }^{1}$, Zhenyu Wang ${ }^{1}$, Yurong Wang ${ }^{1}$

5

6

${ }^{1}$ School of Biological and Chemical Engineering, Liaoning Institute of Science and Technology, Benxi, Liaoning Province, China

Yajing Shi and Zhenyu Wang are equal co-authors.

Corresponding Author:

Zhenyu Wang ${ }^{1}$

No. 176, Xianghuai Street, Benxi, Liaoning Province, 117004, China, Email address:wzy150618@sina.com

\section{Abstract}

Background. The mushroom industry produces a large amount of spent mushroom substrate (SMS), which requires a large geographical footprint and causes pollution.

Methods. We sought to optimize the $\mathrm{C}: \mathrm{N}$ ratio of the initial feedstock used in vermicomposting of SMS by adding pig manure additions. We applied five treatments to the initial feedstock (S0, $\mathrm{S} 1, \mathrm{~S} 2, \mathrm{~S} 3$, and S4) with different C:N ratio of approximately $35,30,25,20$, and 15 , respectively.

Results. Our results showed that lignin and cellulose in SMS were degraded after 56 days vermicomposting, especially in S2 (77.05\% and $45.29 \%$, respectively) and S3 (65.05\% and $48.37 \%$, respectively) treatments. We observed the degradation of the fibrous structure in SMS using pig manure treatments after vermicomposting by microscope and scanning electron microscope. Cellulase and polyphenol oxidase (PPO) were enhanced in pig manure treatments during vermicomposting, especially in the $\mathrm{S} 2$ and $\mathrm{S} 3$ treatments. The biomass of earthworms in the S2 treatments was at its highest level among all treatments at 28 to 56 days. The high level of PPO activity in the S2 treatment may protect cellulase and earthworms against the aromatic toxicity that is a byproduct of lignin degradation, particularly at 28 to 56 days of vermicomposting. Conclusively, it indicated that the $\mathrm{C} / \mathrm{N}$ ratio of 25 in the $\mathrm{S} 2$ treatment was the optimal for SMS vermicomposting with the addition of pig manure. Our results provide a positive application for the recycling of both SMS and pig manure.

\section{Introduction}

Global mushroom production has increased more than 30 fold since 1978, from about 106 metric tons in 1978 to $3.4 \times 10^{7}$ metric tons in 2013(Daniel et al., 2017). China is a major mushroom producer, accounting for 87 percent of global production in 2013 (Daniel et al., 2017). Mushroom output reached at $3.78 \times 10^{7}$ metric tons in China in 2018 alone (Chinese Edible Fungi Association, 2019). One $\mathrm{kg}$ harvest of mushrooms will result in $5 \mathrm{~kg}$ of spent mushroom 
40

41

42

43

substrates (SMS) (Jordan et al., 2008). For example, the output of Lentinula reached $1.04 \times 10^{7}$ metric tons in 2018 (Chinese Edible Fungi Association, 2019), which resulted in over 5.2×107 metric tons of SMS in 2018. Untreated SMS may cause environmental problems, and the recycling or disposal of SMS is a crucial issue, especially in China.

Traditionally, SMS is disposed of by directly returning the waste to the field and composting, which has some practical disadvantages. (1) SMS directly returned to the croplands may cause nitrogen competition between the crops and the microbes in the soil due to the high carbon content of SMS. It may harm crop growth, at least in the short term. (2) If SMS was processed by compost, the compost pile typically contains at least nearly a ton of agricultural waste, which occupies a large footprint on land. The composting process itself often requires professional technical support to turn the compost, and lasts for 90 to 120 days phase of treatment (Busato et al., 2012). These considerations make it difficult for Chinese farmers and other mushroom producers to deal with SMS. However, vermicomposting can be piled any size and can be composted in 21 to 60 days (Suthar and Singh, 2008). It requires minimal materials and does not need complicated skills such as the turning and sealing required for in composting. Maintaining vermicomposting only requires adding water to the pile when necessary. Thus, vermicomposting may be an efficient way to dispose of SMS.

Moreover, the product of SMS vermicomposting could replace a portion of inorganic fertilizers (Jat and Ahlawat, 2006). A study showed that the germination rates of maritime pine were increased by $16 \%$ after the addition of vermicompost into growing media (Lazcano et al., 2010). Germination rates and early growth of wheat were also enhanced by vermicompost amendment (Hussain et al., 2016). The growth of shoots, roots, and leaves in the seedlings of tomato and French marigold were improved by the addition of vermicompost (Bachman and Metzger, 2008). Moreover, the C, N, P, K, Ca, Mg, L-ascorbic acid, glucose, and fructose content in tomato fruits were also increased with the addition of vermicompost (Zaller, 2007).

The vermicomposting is a process accomplished by the interaction of earthworms and microbes. The $\mathrm{C}: \mathrm{N}$ ratio of the initial feedstock is vital in vermicomposting and influences the growth and activity of microbes and earthworms (Aira et al., 2006; Biruntha et al., 2020). Firstly, a high $\mathrm{C}: \mathrm{N}$ ratio treatment slows microbial decomposition by limiting nitrogen (Eiland et al., 2001). A low C:N ratio treatment decreases the microbes activity by exhausting carbon nutrients (Eiland et al., 2001). Kumar et al. (2012) reported that C:N ratios from 13.9 to 19.6 were the optimal for composting. Secondly, the $\mathrm{C}: \mathrm{N}$ ratio of the initial feedstock influences on the living condition of earthworms as well. Schönholzer et al. (1998) reported that the palatability of different leaves to earthworms was dependent upon their $\mathrm{C}: \mathrm{N}$ ratio. Empirical results showed that the best vermicomposting would have a $\mathrm{C}: \mathrm{N}$ ratio of 25 (Ndegwa and Thompson, 2000) and successful vermicomposting is dependent on the correct. Therefore, it is crucial to optimize N-rich substances when adjusting the initial feedstock with C-rich SMS for successful vermicomposting.

Animal manure contains high levels of nitrogen. For example, the values of C:N ratios in the manure of layer hens, pigs, and beef cattle are approximately 10, 13, and 25, respectively. The 
80

81

82

83

84

85

86

87

88

89

90

91

92

93

94

95

96

97

98

99

100

101

102

103

104

105

106

107

108

109

110

111

112

113

114

115

116

117

118

119

global output of beef cattle reached 296 million in 2018. In China, approximately 1,105 million layer-hens, 396 million pigs, and 44 million beef cattle were slaughtered in 2018. The production of poultry and livestock creates a vast amount of animal manure that must be processed (Rehman et al., 2017). Each layer hen, pig, and beef cattle is estimated to produce about $34 \mathrm{~kg}$, $2000 \mathrm{~kg}$, and 11,700 kg of manure annually, respectively (United States Government

Accountability Office, 2008). Of these sources, pig manure with the higher $\mathrm{N}$ content and the largest amount, is most suitable for use in vermicomposting SMS.

Little research has been conducted on vermicomposting SMS with pig manure. There are even fewer studies focused on the physical, chemical, and biological changes of the materials during vermicomposting. He et al. (2017) used Fourier transform infrared (FTIR) spectroscopy, scanning electron microscopy (SEM) and Brunauer-Emmett-Teller (BET) to determine the structural changes of the vermicompost product. Gong et al. (2019) reported on the chemical and biological changes of SMS, such as the biomass of earthworms, and the contents of cellulose and lignin during vermicomposting. These changes directly reflect the degradation of vermicompost materials. We conducted a single factor study of vermicomposting to dispose of SMS with the $\mathrm{C}: \mathrm{N}$ ratio as the variable.

We evaluated the optimal proportion of pig manure addition in SMS vermicomposting based on its physical, chemical, and biological parameters. We used the paraffin method and scanning electron microscopy (SEM) detection to assess the physical properties of SMS. The lignocellulose content and EC values were measured to evaluate the chemical properties of SMS. The biomass of earthworm and enzyme were used to analyze the biological changes of SMS. These measurements contributed to understanding the mechanism of the SMS vermicomposting process, especially the decomposition of lignocellulose.

\section{Materials \& Methods}

\section{Experimental design}

SMS was collected from a mushroom farm in Benxi, China near the Liaoning Institution of Science and Technology. The medium used in shiitake production is generally composed of $49 \%$ wood chips, $30 \%$ cottonseed shell, $15 \%$ bran, $5 \%$ corn flour, and 1\% gypsum. The cellulose and lignin content in SMS were $32.32 \%$ and $6.74 \%$, respectively. Pig manure was collected from a pig farm near the Liaoning Institution of Science and Technology. All nonbiological material such as plastic, stone, and glass were removed manually from the SMS before the experiment.

We used five treatments with different $\mathrm{C}: \mathrm{N}$ ratios in the initial feedstock. The $\mathrm{C}$ content of SMS and pig manure was 193.2 and $259.4 \mathrm{~g} \mathrm{~kg}^{-1}$, respectively, and the $\mathrm{N}$ content of SMS and pig manure were 68.1 and $202.5 \mathrm{~g} \mathrm{~kg}^{-1}$, respectively. The amounts of SMS and pig manure were calculated according to the different $\mathrm{C}: \mathrm{N}$ ratios. The $\mathrm{C}$ and $\mathrm{N}$ content were measured following the procedure in the physicochemical characteristics. In details, SMS and pig manure were mixed with different C:N ratios of approximately 35, 30, 25, 20, and 15 in S0 (SMS $300 \mathrm{~g}$ ), S1(SMS $297 \mathrm{~g}$ and pig manure $3 \mathrm{~g}$ ), S2 (SMS $270 \mathrm{~g}$ and pig manure $30 \mathrm{~g}$ ), S3 (SMS $225 \mathrm{~g}$ and pig manure $75 \mathrm{~g}$ ), and S4 (SMS $180 \mathrm{~g}$ and pig manure $120 \mathrm{~g}$ ), respectively. Three hundred grams 
120 of initial feedstock (dry weight) were placed in a $1 \mathrm{~L}$ glass beaker and $200 \mathrm{~mL}$ water was added

121

122

123

124

125

126

127

128

129

130

131

132

133

134

135

136

137

138

139

140

141

142

143

144

145

146

147

148

149

150

151

152

153

154

155

156

157

158

159

and left to sit for one week. Earthworms were handpicked, washed, and placed in a container with wet filter paper overnight to let the worms empty their gut contents. We chose adult worms with a reproductive ring with individual weights between 0.35 and $0.45 \mathrm{~g}$. The biomass of the earthworms was the weight of worms with empty guts. Earthworms were added at 5 pieces per $100 \mathrm{~g}$ feedstock. Thirty earthworms (Eisenia fetida) were placed in each container into S0, S1, S2, S3, and S4 treatments, respectively. There were four replicates in each treatment and total 100 microcosms (A $1 \mathrm{~L}$ glass beaker, covered with two layers of gauze to allow for aeration, used for destructive sampling). All of the microcosms with the earthworm and SMS mixture were cultured in an artificial climate chamber at $25^{\circ} \mathrm{C}$ with $60-70 \%$ humidity. Vermicomposting lasted for 56 days and the moisture content was maintained at $60 \pm 10 \%$ using distilled water once a week in proportion to the weighted loss of moisture. No other feed materials were added during the 56 days of vermicomposting. Subsamples from the different treatments were collected every two weeks. At the sampling day, earthworms were manually handpicked on each sample day and the indicators of SMS were measured.

\section{Physical characteristics of SMS vermicomposting}

We collected subsamples from each treatment on day 56 of vermicomposting. The subsamples were dried at $45{ }^{\circ} \mathrm{C}$ to a constant weight using drying oven.

After drying, the subsample in each treatment was embedded in melted paraffin at $50-60{ }^{\circ} \mathrm{C}$ and solidified at room temperature. The subsample was immobilized by overnight placement. The subsample was sectioned with a paraffin slicer. Sections were supported on glass slides coated with an adhesive (a mixture of egg whites and glycerin) and placed in a water bath at 45 ${ }^{\circ} \mathrm{C}$. The sections were dewaxed and Canada gum were added for observation. We used a microscope to obtain microscopic images of SMS.

The subsample in each treatment was placed on conductive tape and cleared subsamples without adhesion. After spraying, the subsamples were observed with SEM (Thermo Fisher, Quanta 250).

\section{Physicochemical characteristics of SMS vermicomposting}

The total organic carbon content was determined using potassium dichromate oxidation spectrophotometry (Nelson \& Sommers, 1996). Total nitrogen (TN) was determined using the Kjeldahl method (Jackson, 1973). The pH value and electrical conductivity (EC) were measured using the potentiometric method.

The cellulose and lignin contents were estimated using the Van Soest method (Van Soest et al., 1991) with some modifications. A five-gram sample was heated to boiling in $100 \mathrm{ml}$ of neutral detergent (Sodium Lauryl Sulphate $30 \mathrm{~g} \mathrm{~L}^{-1}$, Ethylene Diamine Tetraacetic Acid (EDTA) $18.6 \mathrm{~g} \mathrm{~L}^{-1}$, boric acid $6.8 \mathrm{~g} \mathrm{~L}^{-1}, \mathrm{Na}_{2} \mathrm{HPO}_{4} 4.56 \mathrm{~g} \mathrm{~L}^{-1}$, and diethyl ether $10 \mathrm{~mL} \mathrm{~L}^{-1}$ ) plus $50 \mu 1$ of heat stable amylase to remove any starch. The sample were heated in ethanol and filtered to remove any lipids; $\mathrm{H}_{2} \mathrm{SO}_{4}$ was added $(1 \mathrm{~N})$ Cetrimonium Bromide $\left(\mathrm{CTAB}, 20 \mathrm{~g} \mathrm{~L}^{-1}\right)$ to remove any protein. The pretreated sample was dried and $0.1 \mathrm{~g}$ of the pretreated sample was added to 10 $\mathrm{mL}$ acetic acid $\left(10 \mathrm{~g} \mathrm{~L}^{-1}\right)$ to determine the amount of cellulose. Alternatively, the pretreated 
160

161

162

163

164

165

166

167

168

169

170

171

172

173

174

175

176

177

178

179

180

181

182

183

184

185

186

187

188

189

190

191

192

193

194

195

196

197

198

sample was added to $10 \mathrm{~mL}$ acetic acid plus nitric acid (1:1, volume by volume), shaken for 5 min, centrifuged for 10 minutes at $8000 \mathrm{~g}$ to collect andy deposits, and then $3 \mathrm{~mL} \mathrm{H}_{2} \mathrm{SO}_{4}(12 \mathrm{~mol}$ $\mathrm{L}^{-1}$ ) was added and left overnight to completely dissolve any cellulose. $10 \mathrm{~mL}$ water was then added, stirred, and heated to boiling for 10 minutes; $0.5 \mathrm{~mL} \mathrm{BaCl}_{2}\left(100 \mathrm{~g} \mathrm{~L}^{-1}\right)$ was added, stirred, and centrifuged for 10 minutes at $8000 \mathrm{~g}$ to collect deposits. $10 \mathrm{~mL}$ potassium dichromate sulfate solution $(0.5 \mathrm{~N})$ was added to this and heated to boiling with constant stirring. The remaining deposits were washed with $10 \mathrm{~mL}$ water. Mohr's salt solution titration was used to determine the cellulose content and iodometry was used to measure the lignin content in SMS.

\section{Biological characteristics of SMS vermicomposting}

The biomass, survival rate and mortality rate of earthworm

Earthworms were collected from all treatments by hand every two weeks. They were washed, allowed to dry on filter paper, and weighed. The biomass, survival rate, and mortality rate of the earthworms were recorded.

The activities of cellulase and polyphenol oxidase (PPO)

Cellulase activity was analyzed according to the method of Borgna (2004) and the reducing sugar generated from carboxymethyl cellulose sodium salt we quantified with some modifications. The reducing sugar content was determined using a method of 3,5-dinitrosalicylic acid (DNS). Five grams of sample were diluted with $0.1 \mathrm{M}$ Sodium acetate buffer (pH 5.5) to $100 \mathrm{~mL}$ and incubated at $4{ }^{\circ} \mathrm{C}$ for $24 \mathrm{~h}$. After 10 minutes of equilibrium, $2 \mathrm{~mL}$ diluent mixed with $5 \mathrm{~mL}$ DNS solution ( $3.15 \mathrm{~g} \mathrm{~L}^{-1} \mathrm{DNS}, 91 \mathrm{~g} \mathrm{~L}^{-1}$ sodium tartrate, $2.5 \mathrm{~g} \mathrm{~L}^{-1}$ phenol, and $2.5 \mathrm{~g} \mathrm{~L}^{-}$ ${ }^{1}$ sodium sulfite), and $2 \mathrm{~mL}$ carboxymethyl cellulose sodium salt $\left(0.8 \mathrm{~g} \mathrm{~L}^{-1}\right)$ was added and incubated for $30 \mathrm{~min}$ under $37^{\circ} \mathrm{C}$. The rate of change was determined spectrophotometrically at $540 \mathrm{~nm}$. One unit (U) of cellulase activity is the production of $1 \mu \mathrm{g} \mathrm{mL}^{-1}$ reducing sugar from 4 $\mathrm{mg} \mathrm{mL} \mathrm{L}^{-1}$ carboxymethyl cellulose sodium salt amount within one minute under $37^{\circ} \mathrm{C}$.

The PPO activity was determined according to the method of Gawlik-Dziki et al. (2008) with modification. A $5 \mathrm{~g}$ sample was mixed with $100 \mathrm{mM}$ catechol and $0.1 \mathrm{M} \mathrm{K}$-phosphate buffer (pH 6.88), and incubated for $10 \mathrm{~min}$ under $40{ }^{\circ} \mathrm{C}$. Then added $2 \mathrm{~mL}$ trichloroacetic acid (20\%) was added to stop the enzymatic reaction and the rate of change was determined spectrophotometrically at $410 \mathrm{~nm}$. One unit (U) of enzyme activity was calculated as the amount of enzyme required for an increase of 0.001 in the absorbance value in one minute.

Seed germination, root and shoot growth in seedling time

Aqueous extracts were prepared from five treatments with distilled water $(1: 80 \mathrm{w} / \mathrm{v})$. The phytotoxicity of these extracts was evaluated through a seed germination test according to the procedures of Abdullahi et al.(2008) with some modifications. A seed germination bioassay for maize was evaluated in which the Whatman filter paper was placed inside a sterilized petri dish and wetted with extracts. 25 corn seeds were placed on top of filter paper and incubated for five days in the dark at $25^{\circ} \mathrm{C}$. The experimental control used filter paper wetted with sterilized water. Seed germination, the percentage of relative seed germination (RSG, relative root elongation (RRG), and the germination index (GI) were calculated (Tiquia \& Tam, 1998). 
199

200

201

202

203

204

205

206

207

208

209

210

211

212

213

214

215

216

217

218

219

220

221

222

223

224

225

226

227

228

229

230

231

232

233

234

235

236

237

238

The results were reported as the mean of four replicates with standard error (SE). One-way ANOVA with Tukey's HSD test was used to test the effect of different pig manure additions on the degradation rates of the fibrous structure in SMS, the chemical properties of the vermicompost products, earthworm biomass, and enzyme activities, and seed germination. The general linear-regression analysis was used to investigate the relationships in the $\mathrm{C}: \mathrm{N}$ ratio, the contents of lignin and cellulose, the activities of cellulase and PPO, and the biomass of earthworms. The probability level used for statistical significance was $p<0.05$ for all tests. SPSS 18.0 (SPSS Inc., Chicago, IL, USA) was used for statistical analyses.

\section{Results}

\section{Physical characteristics of SMS vermicomposting}

The microscopic images of the SMS paraffin section before and after vermicomposting are shown in Fig. 1. After 56 days of vermicomposting, the fibrous structure of SMS was affected by the $\mathrm{C} / \mathrm{N}$ ratio in the initial vermicomposting feedstock, especially in the degree of fragmentation in SMS. The paraffin section presented with changes in the fibrous structures in SMS. A number of fibrous structures are seen in slides A, B, and F, and there were less fibrous structures in C and D. The decrease of fibrous structures demonstrates the degradation of lignocellulose. The degree of fragmentation in SMS increased from 15 to 20 of the C:N ratios and decreased from 25 to 35 of the C:N ratios. The degree of fragmentation was similar between the S2 and S3 treatments. There were more fragments in the S2 and S3 treatments compared with the others.

The SEM images of SMS before and after vermicomposting are shown in Fig. 2. The SEM images show the bright and smooth areas as unbroken fibrous structures in SMS. The fragmented areas show the degraded fibrous structures of SMS. The dark area in the middle of the figure reveals the holes of SMS (such as the porous cob of corn). The SMS surface was relatively smooth before vermicomposting with occasional fragments (Fig. 2A). After vermicomposting, the surfaces of SMS became rough, cracked, porous, and fragmented. The degradation rate of SMS increased with the addition of pig manure among the S0, S1, and S2 treatments (Fig.2). The degradation rates of SMS between S2 and S3 were similar. However, further increasing of pig manure addition weakened degradation rates of SMS in S4 treatment.

\section{Chemical characteristics of SMS vermicomposting}

The values of EC fluctuated in all the treatments during the 56 days cultivation period (Table 1). The EC values in the treatments increased with cultivation with the exception of the S1 treatment. The EC values were $578 \mu \mathrm{m} \mathrm{cm}^{-1}$ and $615 \mu \mathrm{m} \mathrm{cm}^{-1}$ in the S3 and S4 treatments, respectively. The EC values were $64.48 \%$ and $55.47 \%$ higher in the S3 and S4 treatments than the control, respectively.

TOC and TN decreased in all treatments (Table 1). The vermicompost system led to a decreasing in nutrients during cultivation. The TOC content in the vermicompost treated with pig manure was similar in value and was higher than that without pig manure. The TN results had a similar tendency to TOC. The nutrients in the SMS mixtures rapidly degraded during the first 28 days and then slowed their consumption between days 28 to 56 . The invariant of TOC and TN 
239 showed a similar tendency with the nutrient consumption in the vermicompost system. A slower

240

241

242

243

244

245

246

247

248

249

250

251

252

253

254

255

256

257

258

259

260

261

262

263

264

265

266

267

268

269

270

271

272

273

274

275

276

277

nutrient consumption signaled the end of the vermicomposting.

Lignin and cellulose degradation increased with the vermicomposting process was affected by the addition of pig manure (Fig. 3A and 3B). The degradation rates of cellulose were $22.44 \%$, $31.36 \%, 45.29 \%, 48.37 \%$, and $21.61 \%$ in S0, S1, S2, S3, and S4 treatments, respectively, on the $56^{\text {th }}$ day (Fig. 3C). The degradation rates of lignin were $26.86 \%, 58.78 \%, 77.05 \%, 59.05 \%$, and $53.63 \%$ in the S0, S1, S2, S3, and S4 treatments, respectively (Fig. 3D). The degradation rates of cellulose were similar between the $\mathrm{S} 2$ and $\mathrm{S} 3$ treatment, but the degradation rates of lignin were $18.0 \%$ higher in the $\mathrm{S} 2$ treatment than the $\mathrm{S} 3$ treatment.

\section{Biological characteristics of SMS vermicomposting}

(1) The earthworm biomass increased before 28 days and then decreased at 56 days (Table 2). The earthworm biomass increased with the addition of more pig manure in the S0, S1, and S2 treatments. The highest earthworm biomass was on day 28 in the S2 treatment among all treatments. Earthworm mortality was higher in the $\mathrm{S} 0$ treatment than other treatments at the end of the vermicomposting process (One-way ANOVA, $\mathrm{F}=81.36, p<0.05$ ). Earthworm mortality was over $90 \%$ in the S0 treatment but was more than $73 \%$ in the S4 treatment. Earthworm mortality was approximately $25 \%$ in the S1 and S3 treatments. There was only one earthworm dead in one replicate of the $\mathrm{S} 2$ treatment during cultivation. The earthworm mortality decreased with the increase of pig manure addition among the S0, S1, and S2 treatments. However, further increasing of pig manure enhanced the earthworm mortality in S3 and S4 treatments.

(2) Fig. 4 shows the results of the seed germination test with a $1.25 \%$ extraction of vermicompost products in all treatments. The Germination Index (GI) in all treatments was greater than $80 \%$. The GI in the S2 treatment showed $36.09 \%, 10.29 \%$, and $19.75 \%$ higher than that of the S0, S3, and S4 treatment, respectively.

(3) The cellulase activity was affected by different levels of pig manure addition (Fig. 3E). At 42 days, the cellulase activities in the $\mathrm{S} 3$ treatment reached its peak value $(45.02 \pm 0.04 \mathrm{mg}$ glucose $\mathrm{g}^{-1} \mathrm{~min}^{-1}$ ) and was higher than that of the other treatments. At 56 days, the activities of cellulase showed higher in the $\mathrm{S} 2$ and $\mathrm{S} 3$ treatments than other treatments, but there were differences between the S2 and S3 treatments. The cellulase activities were lower in the S4 treatment than that of $\mathrm{S} 0$ and $\mathrm{S} 1$ treatments.

(4) PPO activity was increased by the addition of pig manure (except in the S4 treatment at 56 days) (Fig. 3F). At 56 days, an increased amount of pig manure decreased the PPO activity among pig manure addition treatments. The PPO activities ranged from greatest to least as 72.05 $\pm 6.93,64.67 \pm 4.37,62.01 \pm 6.12$, and $25.33 \pm 4.62 \mathrm{U} \mathrm{g}^{-1} \mathrm{~min}^{-1}$ in the S2, S1, S3, and S4 treatments, respectively.

\section{Discussion}

The high content of lignocellulose in SMS limited its degradation, which is an index to evaluate the efficiency of vermicomposting. We evaluated the changes in the physical, chemical, and 
278 biological properties in SMS to assess the effect of adding different amounts of pig manure for

279 successful lignocellulose decomposing.

280 Changes of physical characteristics in SMS vermicomposting

281 Vermicomposting changed the structure of the SMS feedstock. Microscopic images showed the

282 fiber structure in SMS was reduced by vermicomposting (Fig. 1) that the change was affected by

283 adding different amounts of pig manure.

284 The fiber structure was most reduced in the S2 and S3 treatments when compared with the 285 initial SMS. These results indicated that the C:N ratios of the initial feedstock at 20 and 25 was 286 beneficial for SMS vermicomposting. Secondly, SEM images showed that SMS was destroyed 287 and degraded by vermicomposting (Fig. 2). This explained the reduction of fiber structures seen 288 in microscopic images of SMS. SEM images in this study were in agreement with those from 289 previous studies (Gong et al., 2019; He et al., 2017; Soobhany et al., 2015). The more fragments 290 were seen in SMS implied a greater amount of degradation by vermicomposting. Fragmented 291 SMS was beneficial to earthworm feeding and microbial contact. The fragmentation of the 292 vermicomposting product is helpful for providing nutrients to plants. Thus, the C:N ratios of 20 293 and 25 in the initial feedstock were best for successful SMS vermicomposting.

294 Changes of chemical characteristics in SMS vermicomposting

295 Lignocellulose includes cellulose, lignin, and hemicellulose, which are the major structural 296 components of plant material. The SMS used in our study contained $32.32 \%$ cellulose and $6.74 \%$ 297 lignin (see results) and lignocellulose was the most prevalent fibrous structure in SMS. The 298 recalcitrant lignin protects cellulose from degradation (Schmidt et al., 1995). The degradation of 299 lignocellulose determined the degradation of the fibrous structures in SMS. Vermicomposting 300 induced fragmentation and degradation of the fiber structure in SMS (Fig. 1), which was similar 301 to the results of Gong et al. (2019).

302 Vermicomposting is a process involving collaboration between earthworms and microbes. The 303 SMS feedstock properties influence the feeding of the worm and the resulting microorganisms. 304 The degradation of lignocellulose was affected by the dietary preferences and lifestyle habits of 305 earthworms. The degradation of lignocellulose in vermicompost needs to happen in a 306 nitrogenous environment such as in a sludge and animal waste matrix. E. fetida has been shown 307 to decrease the cellulose content in paper mill sludge (Negi and Suthar, 2018). Our correlation 308 analysis showed that the content of cellulose was negatively correlated with cellulase and the 309 biomass of earthworms, which confirmed earthworms ingested and degraded cellulose on $28^{\text {th }}$ 310 and $56^{\text {th }}$ day (Table 3). The swallowing and digesting of the worm were affected by SMS 311 properties like the size of the parts. The initial SMS feedstock used in our study was a mixture of 312 SMS and pig manure, which was composed of a variety of particles sizes. SMS mainly contains 313 large particles, such as parts of corn cobs and sawdust. Pig manure is composed of many highly 314 digested small particles. The addition of pig manure enhanced the proportion of small particles in 315 SMS, which is beneficial for earthworm feeding. However, Pig manure is rich in ammonia and 316 adding too much pig manure to SMS feedstock with its excessive amine content can be toxic to 317 earthworms. Reasonable SMS feedstock should enhance the biomass of worms and promote 
318 SMS degradation. The addition of pig manure provided $\mathrm{N}$ nutrient for microbial growth and

319 enhanced SMS degradation by microorganisms. Our results indicated that the suitable C:N ratio 320 of initial feedstock in SMS vermicomposting was 20 or 25.

321 Changes of biological characteristics in SMS vermicomposting

322 The biomass of earthworms generally increased within 28 days and decreased at 56 days (Table

323 2). Earthworm biomass was affected by the addition of pig manure. Within 28 days, the

324 earthworm biomass increased in the S1, S2, and S3 treatments if the nutrient supply was

325 sufficient, which is similar to the results of Gong et al. (2019). From 28 to 56 days, the decrease

326

327

328

329

330

331

332

333

334

335

336

337

338

339

340

341

342

343

344

345

346

347

348

349

350

351

352

353

354

355

356

357 of earthworm biomass indicated nutrients depletion. The lowest mortality and highest biomass of earthworms in the S2 treatment demonstrated that it provided the best nutrient supply among all treatments. The meant S2 treatment provided sustainable conditions for SMS vermicomposting. The production, stimulation, and inhibition factors of cellulase regulated vermicomposting activity. (1) Earthworms and microbes produce cellulose and the physiological conditions of earthworms and microorganisms can affect their secretion of cellulose. A proper $\mathrm{C}: \mathrm{N}$ ratio of initial feedstock aids in growth and lifecycle of worms and microbes, which increase the activities of cellulase in vermicomposting (Aira et al., 2006). The addition of pig manure can alter the C:N ratio of initial SMS feedstock. In this study, SMS feedstock supply determined the nutrients content for earthworms and microbes. The gradients of pig manure added to SMS resulted in variations of cellulose. There was a positive correlation between earthworm biomass and cellulase. The biomass of earthworms was positively correlated with the activities of cellulase and PPO on $28^{\text {th }}$ and $56^{\text {th }}$ day (Table 3 ), which indicated that the higher biomass of earthworms could increase the activities of cellulase and PPO. Similarly, Gong et al. (2019) reported that vermicompost enhanced the activities of cellulase, urease, and alkaline phosphatase. Our results verified that a greater biomass of earthworms would secrete more cellulase. (2) There were some stimulation factors affecting cellulase activity in vermicomposting. In this study, EC was increased by vermicompost in each treatment (Table 1), which meant that vermicomposting may enhance the fluidity of some metal ions. Previous reports showed that metal ions such as $\mathrm{Ca}^{2+}, \mathrm{Mg}^{2+}, \mathrm{Mn}^{2+}, \mathrm{Zn}^{2+}, \mathrm{Pb}^{2+}, \mathrm{Fe}^{2+}$, and $\mathrm{Fe}^{2+}$ had a positive influence on cellulase activity (Chen et al., 2019; Pachauri et al., 2018). The EC values and cellulase showed the same fluctuating trends as the $\mathrm{C}: \mathrm{N}$ ratio of the initial feedstock. The higher EC values may illustrate the greater cellulase activities in the S2 treatment on 28, 42, and 56 days. (3) There were some inhibitory factors affecting cellulase activity in vermicomposting. Two lignin preparations can suppressed the six cellulases and one recombinant -1,4endoglucanase (Berlin et al., 2006). Lignin contains three aromatic alcohols (coniferyl alcohol, sinapyl alcohol, and p-coumaryl alcohol) (Calvo-Flores \& Dobado, 2010; Jiang et al., 2010; Menon \& Rao, 2012). The aromatic substances can destroy the structure of cellulase and reduce its effects on vermicomposting. The removal of compounds with aromatic rings can effectively protect cellulase activity. PPO converted part of the aromatic compounds into quinones, which protected cellulase. During vermicomposting, the PPO activities were higher in the S2 treatment than the other treatments. Most of the phenols and the sesquiterpene lactones in parthenium were 
358

359

360

361

362

363

364

365

366

367

368

369

370

371

372

373

374

375

376

377

378

379

380

381

382

383

384

385

386

387

388

389

390

391

392

393

394

395

396

397

398

399

400

401

degraded by vermicomposting (Hussain et al., 2016). The protection of PPO may have resulted in the high cellulase activity in the S2 treatment.

The GI values of the vermicomposting products were higher than $100 \%$, following the judgment standard of McLachlan et al. (2004). The vermicomposting products of SMS were non-phytotoxic.

\section{Conclusions}

The addition of pig manure promoted the fragmentation of SMS, enhanced the decomposition of lignocellulose, and increased the activities of cellulase and PPO in the SMS vermicomposting system. Physiochemically, the fragmentation of SMS and decomposing of lignocellulose increased with the addition of pig manure in the S0, S1, and S2 treatments, and decreased with the increased addition of pig manure in the S3 and S4 treatments. Biologically, the survival and biomass of earthworms were higher in the S2 group than the others. The activities of cellulase and PPO were at a high level in S2 treatment. It indicated that the changes of physical, chemical, and biological characteristics in SMS vermicomposting are directly related to the initial SMS feedstocks with different addition of pig manure. And it suggested that the optimal vermicomposting condition was the $\mathrm{C} / \mathrm{N}$ ratio of initial feedstock at 25 .

\section{References}

Abdullahi YA, Akunna JC, White NA, Hallett PD, Wheatley R. 2008. Investigating the effects of anaerobic and aerobic post-treatment on quality and stability of organic fraction of municipal solid waste as soil amendment. Bioresource Technology 99:6.

Aira M, Monroy F, Domínguez J. 2006. C to N ratio strongly affects population structure of Eisenia fetida in vermicomposting systems. European Journal of Soil Biology 42:S127-S131.

Bachman GR, Metzger JD. 2008. Growth of bedding plants in commercial potting substrate amended with vermicompost. Bioresource Technology 99:3155-3161.

Berlin A, Balakshin M, Gilkes N, Kadla J, Maximenko V, Kubo S, Saddler J. 2006. Inhibition of cellulase, xylanase and $\beta$-glucosidase activities by softwood lignin preparations. Journal of Biotechnology 125:198-209.

Biruntha M, Karmegam N, Archana J, Karunai Selvi B, John Paul JA, Balamuralikrishnan B, Chang SW, Ravindran B. 2020. Vermiconversion of biowastes with low-to-high $\mathrm{C} / \mathrm{N}$ ratio into value added vermicompost. Bioresource Technology 297:122398.

Borgna JL. 2004. Requirements for reliable determination of binding affinity constants by saturation analysis approach. The Journal of Steroid Biochemistry and Molecular Biology 92:419-433.

Busato JG. Lima LS, Aguiar NO, Canellas LP, Olivares FL. 2012. Changes in labile phosphorus forms during maturation of vermicompost enriched with phosphorus-solubilizing and diazotrophic bacteria. Bioresource Technology 110:390-395.

Calvo-Flores FG, Dobado JA. 2010. Lignin as Renewable Raw Material. ChemSusChem 3: 227-1235 https://doi.org/10.1002/cssc.201000157

Chen Y, Wu C, Shen Y, Ma Y, Wei D, Wang W. 2019. N,N-dimethylformamide induces cellulase production in the filamentous fungus Trichoderma reesei. Biotechnology for Biofuels 12, 36. 
402

403

404

405

406

407

408

409

410

411

412

413

414

415

416

417

418

419

420

421

422

423

424

425

426

427

428

429

430

431

432

433

434

435

436

437

438

439

440

441

442

443

444

445

446

447

448

449

450

451

452

Chinese edible fungi association, C., 2019. http://hz.cefa.com.cn/UploadFiles/news/2020/3/202003191756353016.pdf.

Daniel JR, Johan B, Qi T. 2017. Current Overview of Mushroom Production in the World, in: PardoGiménez, D.C.Z.a.A. (Ed.), Edible and Medicinal Mushrooms. John Wiley \& Sons Ltd., pp. 5-13.

Eiland F, Klamer M, Lind AM, Leth M, Bååth E. 2001. Influence of Initial C/N Ratio on Chemical and Microbial Composition during Long Term Composting of Straw. Microbial Ecology 41:272-280.

Gawlik-Dziki U, Zlotek U, Świeca M. 2008. Characterization of polyphenol oxidase from butter lettuce (Lactuca sativa var. capitata L.). Food Chemistry 107:129-135.

Gong X, Li S, Carson MA, Chang SX, Wu Q, Wang L, An Z, Sun X. 2019. Spent mushroom substrate and cattle manure amendments enhance the transformation of garden waste into vermicomposts using the earthworm Eisenia fetida. Journal of Environmental Management 248:109263.

He X, Zhang Y, Shen M, Tian Y, Zheng K, Zeng G. 2017. Vermicompost as a natural adsorbent: evaluation of simultaneous metals $(\mathrm{Pb}, \mathrm{Cd})$ and tetracycline adsorption by sewage sludge-derived vermicompost. Environmental Science and Pollution Research 24:8375-8384.

Hussain N, Abbasi T, Abbasi SA. 2016. Vermicomposting transforms allelopathic parthenium into a benign organic fertilizer. Journal of Environmental Management 180:180-189.

Jackson ML. 1973. Soil Chemical Analysis. Prentice Hall of India, New Delhi.

Jat RS, Ahlawat IPS. 2006. Direct and Residual Effect of Vermicompost, Biofertilizers and Phosphorus on Soil Nutrient Dynamics and Productivity of Chickpea-Fodder Maize Sequence. Journal of Sustainable Agriculture 28:41-54.

Jiang G, Nowakowski DJ, Bridgwater AV. 2010. A systematic study of the kinetics of lignin pyrolysis. Thermochimica Acta 498:61-66.

Jordan SN, Mullen GJ, Murphy, MC. 2008. Composition variability of spent mushroom compost in Ireland. Bioresource Technology 99:411-418.

Kumar L, Arantes V, Chandra R, Saddler J. 2012. The lignin present in steam pretreated softwood binds enzymes and limits cellulose accessibility. Bioresource Technology 103:201-208.

Lazcano C, Sampedro L, Zas R. 2010. Vermicompost enhances germination of the maritime pine (Pinus pinaster Ait.). New Forests 39, 387-400.

McLachlan KL, Chong C, Vorony RP. 2004. Assessing the potential phytotoxicity of digestates during processing of municipal solid waste by anaerobic digestion; a comparison to aerobic digestion. Acta horticulturae 638:225-230 DOI: 10.17660/ActaHortic.2004.638.29

Menon V, Rao M. 2012. Trends in bioconversion of lignocellulose: Biofuels, platform chemicals \& biorefinery concept. Progress in Energy and Combustion Science 38:522-550.

Ndegwa PM, Thompson SA. 2000. Effects of C-to-N ratio on vermicomposting of biosolids. Bioresource Technology 75:7-12.

Negi R, Suthar S. 2018. Degradation of paper mill wastewater sludge and cow dung by brown-rot fungi Oligoporus placenta and earthworm (Eisenia fetida) during vermicomposting. Journal of Cleaner Production 201:842-852.

Nelson DW, Sommers LE. 1996. Total Carbon, Organic Carbon, and Organic Matter, Methods of Soil Analysis. R.H., Miller D.R., Keeney (Eds.), Madison, pp. 961-1010.

Pachauri P, More S, Aranganathan V, Sullia SB. 2018. Kinetic study and characterization of cellulase enzyme from isolated Aspergillus niger subsp. awamori for cellulosic biofuels. J. Sci. Ind. Res. India. 77, 55-60.

Rehman A, Jingdong L, Chandio AA, Hussain I. 2017. Livestock production and population census in Pakistan: Determining their relationship with agricultural GDP using econometric analysis. Information Processing in Agriculture 4:168-177.

Schmidt JA, Rye CS, Gurnagul N. 1995. Lignin inhibits autoxidative degradation of cellulose. Polymer Degradation and Stability 49:291-297.

Schönholzer F, Kohli L, Hahn D, Daniel O, Goez C, Zeyer J. 1998. Effects of decomposition of leaves on bacterial biomass and on palatability to Lumbricus terrestris L. Soil Biology and Biochemistry 30:1805-1813.

Peer] reviewing PDF | (2020:08:52176:1:2:CHECK 11 Nov 2020) 
453

454

455

456

457

458

459

460

461

462

463

464

465

466

467

468

469

470
Soobhany N, Mohee R, Garg VK. 2015. Recovery of nutrient from Municipal Solid Waste by composting and vermicomposting using earthworm Eudrilus eugeniae. Journal of Environmental Chemical Engineering 3:2931-2942.

Suthar S, Singh S. 2008. Vermicomposting of domestic waste by using two epigeic earthworms (Perionyx excavatus and Perionyx sansibaricus). International Journal of Environmental Science \& Technology 5:99-106.

Tiquia SM, Tam NFY. 1998. Elimination of phytotoxicity during co-composting of spent pig-manure sawdust litter and pig sludge. Bioresource Technology 65:43-49.

United States Government Accountability Office. 2008. EPA Needs More Information and a Clearly Defined Strategy to Protect Air and Water Quality from Pollutants of Concern, in: Office, U.S.G.A. (Ed.), pp. 1-85.

Van Soest PJ, Robertson JB, Lewis BA. 1991. Methods for Dietary Fiber, Neutral Detergent Fiber, and Nonstarch Polysaccharides in Relation to Animal Nutrition. Journal of Dairy Science 74, 3583-3597.

Zaller JG. 2007. Vermicompost as a substitute for peat in potting media: Effects on germination, biomass allocation, yields and fruit quality of three tomato varieties. Scientia Horticulturae 112:191199. 


\section{Table $\mathbf{1}$ (on next page)}

Table 1 Physico-chemical characteristics of the various substrates used for vermicomposting.

Physico-chemical characteristics of the various substrates used for vermicomposting. Values are mean \pm standard error $(n=3)$. Means in a row followed by different letters are significantly different at $p \square 0.05$ according to Tukey HSD test. 


\section{Table 1}

2 Physico-chemical characteristics of the various substrates used for vermicomposting. Values are mean \pm standard error

$3(\mathrm{n}=3)$. Means in a row followed by different letters are significantly different at $p<0.05$ according to Tukey HSD 4 test.

\begin{tabular}{llllllll}
\hline & & & & & \multicolumn{2}{c}{$\begin{array}{l}\text { One-way } \\
\text { ANOVA }\end{array}$} \\
\cline { 6 - 8 } Parameters & $\mathrm{S} 0$ & $\mathrm{~S} 1$ & $\mathrm{~S} 2$ & $\mathrm{~S} 3$ & $\mathrm{~S} 4$ & $\begin{array}{l}\mathrm{F} \\
\text { value }\end{array}$ & $\begin{array}{l}\mathrm{P} \\
\text { value }\end{array}$ \\
\hline Initial TN $\left(\mathrm{g} \mathrm{kg}^{-1}\right)$ & $4.71 \pm 0.9^{\mathrm{d}}$ & $5.37 \pm 0.14^{\mathrm{dc}}$ & $6.13 \pm 0.28^{\mathrm{c}}$ & $7.54 \pm 0.29^{\mathrm{b}}$ & $10.19 \pm 0.29^{\mathrm{a}}$ & 64.26 & 0.000 \\
Final TN $\left(\mathrm{g} \mathrm{kg}^{-1}\right)$ & $3.64 \pm 0.37^{\mathrm{d}}$ & $3.59 \pm 0.16^{\mathrm{d}}$ & $4.67 \pm 0.45^{\mathrm{c}}$ & $5.77 \pm 0.21^{\mathrm{b}}$ & $7.05 \pm 0.21^{\mathrm{a}}$ & 75.98 & 0.000 \\
Initial TOC $\left(\mathrm{g} \mathrm{kg}^{-1}\right)$ & $26.32 \pm 0.23^{\mathrm{a}}$ & $25.02 \pm 0.19^{\mathrm{b}}$ & $24.91 \pm 0.29^{\mathrm{c}}$ & $23.76 \pm 0.10^{\mathrm{d}}$ & $22.92 \pm 0.35^{\mathrm{e}}$ & 10.51 & 0.001 \\
Final TOC $\left(\mathrm{g} \mathrm{kg}^{-1}\right)$ & $23.27 \pm 0.35^{\mathrm{a}}$ & $20.51 \pm 0.15^{\mathrm{b}}$ & $20.01 \pm 0.79^{\mathrm{b}}$ & $20.09 \pm 0.22^{\mathrm{b}}$ & $20.12 \pm 0.24^{\mathrm{b}}$ & 5.36 & 0.014 \\
Initial $\mathrm{pH}$ & $8.81 \pm 0.03^{\mathrm{a}}$ & $8.78 \pm 0.04^{\mathrm{a}}$ & $8.74 \pm 0.03^{\mathrm{a}}$ & $8.81 \pm 0.03^{\mathrm{a}}$ & $8.83 \pm 0.03^{\mathrm{a}}$ & 39.35 & 0.000 \\
Final pH & $8.38 \pm 0.14^{\mathrm{a}}$ & $8.14 \pm 0.13^{\mathrm{ab}}$ & $8.01 \pm 0.06^{\mathrm{b}}$ & $7.99 \pm 0.09^{\mathrm{b}}$ & $7.60 \pm 0.12^{\mathrm{c}}$ & 18.11 & 0.000 \\
Initial EC $\left(\mu \mathrm{s} \mathrm{cm}^{-1}\right)$ & $217.00 \pm 9.54^{\mathrm{b}}$ & $202.17 \pm 8.28^{\mathrm{c}}$ & $201 \pm 7.81^{\mathrm{c}}$ & $218.67 \pm 8.02^{\mathrm{b}}$ & $241.00 \pm 6.56^{\mathrm{a}}$ & 12.01 & 0.001 \\
Final EC $\left(\mu \mathrm{s} \mathrm{cm}^{-1}\right)$ & $243.67 \pm 14.22^{\mathrm{c}}$ & $306.67 \pm 12.74^{\mathrm{c}}$ & $395.67 \pm 44.66^{\mathrm{b}}$ & $578.33 \pm 81.09^{\mathrm{a}}$ & $615.67 \pm 13.20^{\mathrm{a}}$ & 44.28 & 0.000 \\
\hline
\end{tabular}

5 


\section{Table 2 (on next page)}

Table 2 Biomass and mortality rates of the earthworm (Eisenia fetida).

Biomass and mortality rates of the earthworm (Eisenia fetida). Values are mean \pm standard error $(n=3)$. Means in a row followed by different letters are significantly different at $p \square 0.05$ according to Tukey HSD test. 


\section{Table 2}

2 Biomass and mortality rates of the earthworm (Eisenia fetida). Values are mean \pm standard error $(\mathrm{n}=3)$. Means in a 3 row followed by different letters are significantly different at $p<0.05$ according to Tukey HSD test.

\begin{tabular}{|c|c|c|c|c|c|c|c|}
\hline \multirow[b]{2}{*}{ Parameters } & \multirow[b]{2}{*}{ S0 } & \multirow[b]{2}{*}{ S1 } & \multirow[b]{2}{*}{ S2 } & \multirow[b]{2}{*}{ S3 } & \multirow[b]{2}{*}{ S4 } & \multicolumn{2}{|c|}{ One-way ANOVA } \\
\hline & & & & & & F value & $P$ value \\
\hline $\begin{array}{l}\text { Mean weight of } \\
\text { earthworm in the initial } \\
\text { time }(\mathrm{g})\end{array}$ & $14.03 \pm 5.5^{\mathrm{a}}$ & $14.79 \pm 8.1^{\mathrm{a}}$ & $14.96 \pm 14.8^{\mathrm{a}}$ & $14.54 \pm 3.0^{\mathrm{a}}$ & $14.50 \pm 16.7^{\mathrm{a}}$ & 1.095 & 0.405 \\
\hline $\begin{array}{l}\text { Mean weight of } \\
\text { earthworm at 28th day } \\
\text { (g) }\end{array}$ & $7.05 \pm 1.05^{\mathrm{d}}$ & $11.5 \pm 1.45^{\mathrm{cd}}$ & $17.6 \pm 1.22^{\mathrm{a}}$ & $13.07 \pm 1.46^{\mathrm{b}}$ & $9.70 \pm 1.03^{\mathrm{c}}$ & 29.69 & $<0.001$ \\
\hline $\begin{array}{l}\text { Mean weight of } \\
\text { earthworm at } 56 \text { th day } \\
\text { (g) }\end{array}$ & $1.13 \pm 0.99^{\mathrm{c}}$ & $5.93 \pm 1.16^{\mathrm{b}}$ & $10.56 \pm 1.03^{\mathrm{a}}$ & $6.01 \pm 0.67^{\mathrm{b}}$ & $2.27 \pm 0.31^{\mathrm{c}}$ & 52.81 & $<0.001$ \\
\hline $\begin{array}{l}\text { Mortality rate after } 28 \\
\text { days }(\%)\end{array}$ & $36.67 \pm 5.77^{\mathrm{a}}$ & $20.00 \pm 6.55^{\mathrm{b}}$ & 0 & $6.67 \pm 1.55^{\mathrm{b}}$ & $23.33 \pm 5.77^{\mathrm{ab}}$ & 10.39 & $<0.001$ \\
\hline $\begin{array}{l}\text { Mortality rate at } 56 \\
\text { days }(\%)\end{array}$ & $90.00 \pm 8.82^{\mathrm{a}}$ & $24.44 \pm 11.7^{\mathrm{c}}$ & $1.11 \pm 1.92^{\mathrm{d}}$ & $26.67 \pm 5.77^{\mathrm{c}}$ & $73.33 \pm 3.33^{\mathrm{b}}$ & 81.36 & $<0.001$ \\
\hline
\end{tabular}

4

5 


\section{Table 3 (on next page)}

Table 3 Correlation coefficients of lignin content, cellulose content, cellulase and PPO activities in treatments with different $\mathrm{C} / \mathrm{N}$ ratios of initial feedstocks.

Table 3 Correlation coefficients of lignin content, cellulose content, cellulase and PPO activities in treatments with different $\mathrm{C} / \mathrm{N}$ ratios of initial feedstocks. $*$ Correlation is significant at the 0.05 level. ** Correlation is significant at the 0.01 level. 
2

3 Table 3 Correlation coefficients of lignin content, cellulose content, cellulase and PPO activities in treatments with 4 different $\mathrm{C} / \mathrm{N}$ ratios of initial feedstocks.

\begin{tabular}{|c|c|c|c|c|c|c|}
\hline & $\mathrm{C} / \mathrm{N}$ ratio & Lignin & Cellulose & Cellulase & PPO & $\begin{array}{l}\text { Biomass of } \\
\text { earthworm }\end{array}$ \\
\hline \multicolumn{7}{|l|}{$28^{\text {th }}$ day } \\
\hline $\mathrm{C} / \mathrm{N}$ ratio & 1 & & & & & \\
\hline lignin & 0.101 & 1 & & & & \\
\hline cellulose & 0.504 & 0.408 & 1 & & & \\
\hline cellulase & $-0.595^{*}$ & 0.027 & $-0.698^{* *}$ & 1 & & \\
\hline PPO & 0.266 & -0.414 & -0.230 & 0.294 & 1 & \\
\hline $\begin{array}{l}\text { biomass of } \\
\text { earthworm }\end{array}$ & -0.266 & -0.283 & $-0.645^{* *}$ & $0.739^{* *}$ & $0.785^{* *}$ & 1 \\
\hline \multicolumn{7}{|l|}{$56^{\text {th }}$ day } \\
\hline $\mathrm{C} / \mathrm{N}$ ratio & 1 & & & & & \\
\hline lignin & 0.324 & 1 & & & & \\
\hline cellulose & $0.529^{*}$ & $0.761^{* *}$ & 1 & & & \\
\hline cellulase & 0.084 & -0.422 & $-0.626^{*}$ & 1 & & \\
\hline PPO & 0.342 & -0.090 & -0.258 & $0.594^{*}$ & 1 & \\
\hline $\begin{array}{l}\text { biomass of } \\
\text { earthworm }\end{array}$ & -0.098 & $-0.665^{* *}$ & $-0.657^{* *}$ & $0.797^{* *}$ & $0.701^{* *}$ & 1 \\
\hline
\end{tabular}

$5 *$ Correlation is significant at the 0.05 level.

$6 * *$ Correlation is significant at the 0.01 level.

7 


\section{Figure 1}

Figure 1. Optical microscope images of SMS in different treatments after 56 days of vermicomposting (600x magnify).

Fig. 1. Optical microscope images of SMS in different treatments after 56 days of vermicomposting (600x magnify). The image A presented the physical characteristics of SMS before vermicomposting (A) under microscope, and the image of $B, C, D, E$ and $F$ presented the physical characteristics of SMS in S0, S1, S2, S3 and S4 treatments after 56 days of vermicomposting under microscope. The arrow shows the fibrous structure of SMS under microscope. The intact and broken fiber structure represents the non-degraded and degraded fiber structure in SMS. 


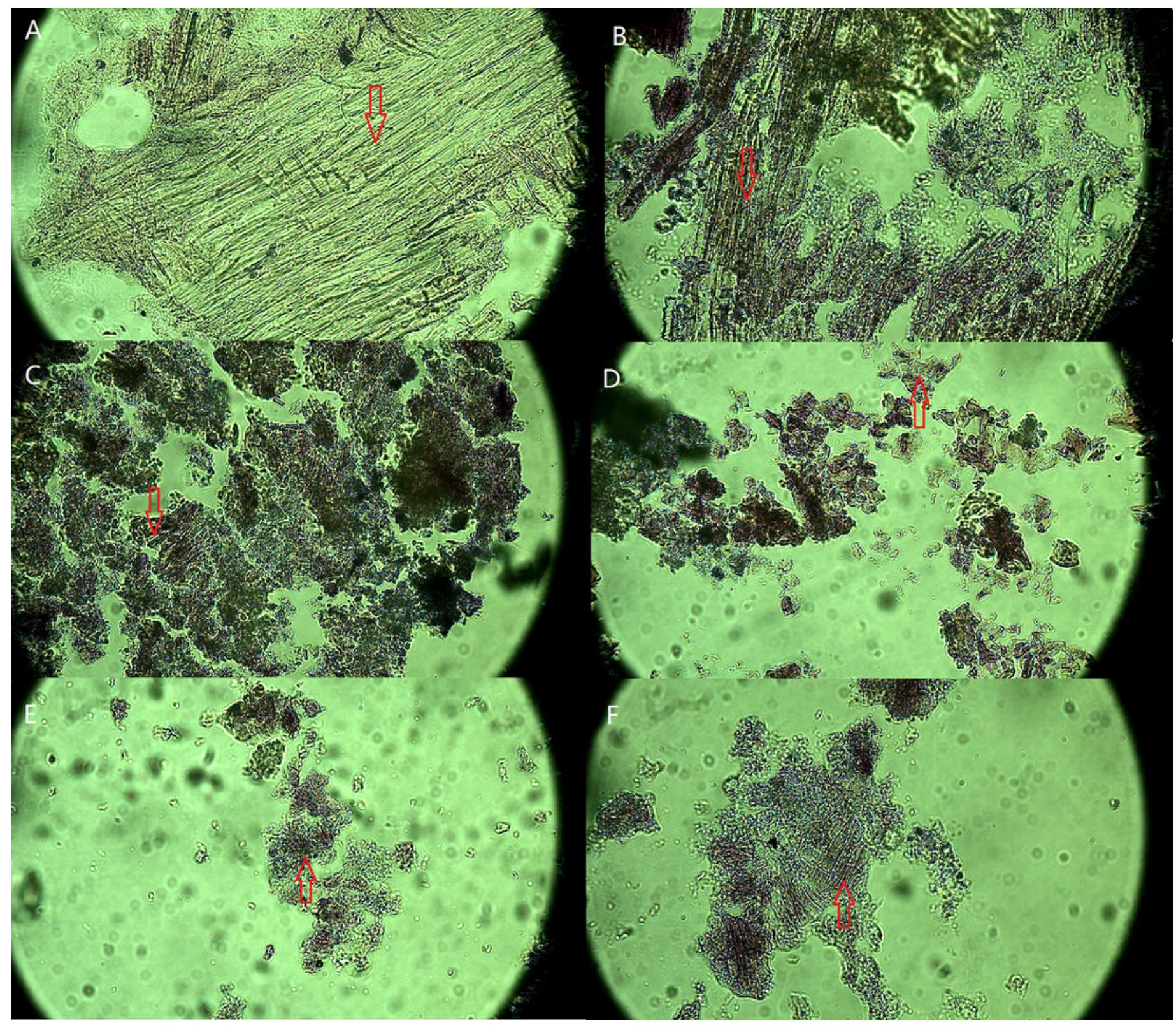




\section{Figure 2}

Figure 2. Scanning electron micrographs (SEM) of SMS in different treatments after 56 days of vermicomposting.

Fig. 2. Scanning electron micrographs (SEM) of SMS in different treatments after 56 days of vermicomposting. The image A presented the physical characteristics of SMS before vermicomposting $(A)$ under SEM, and the image of $B, C, D, E$ and $F$ presented the physical characteristics of SMS in S0, S1, S2, S3 and S4 treatments after 56 days of vermicomposting under SEM. The arrow shows the fibrous structure of SMS under SEM. The smooth and fragmentation structures indicated undegraded and degraded parts in SMS. 


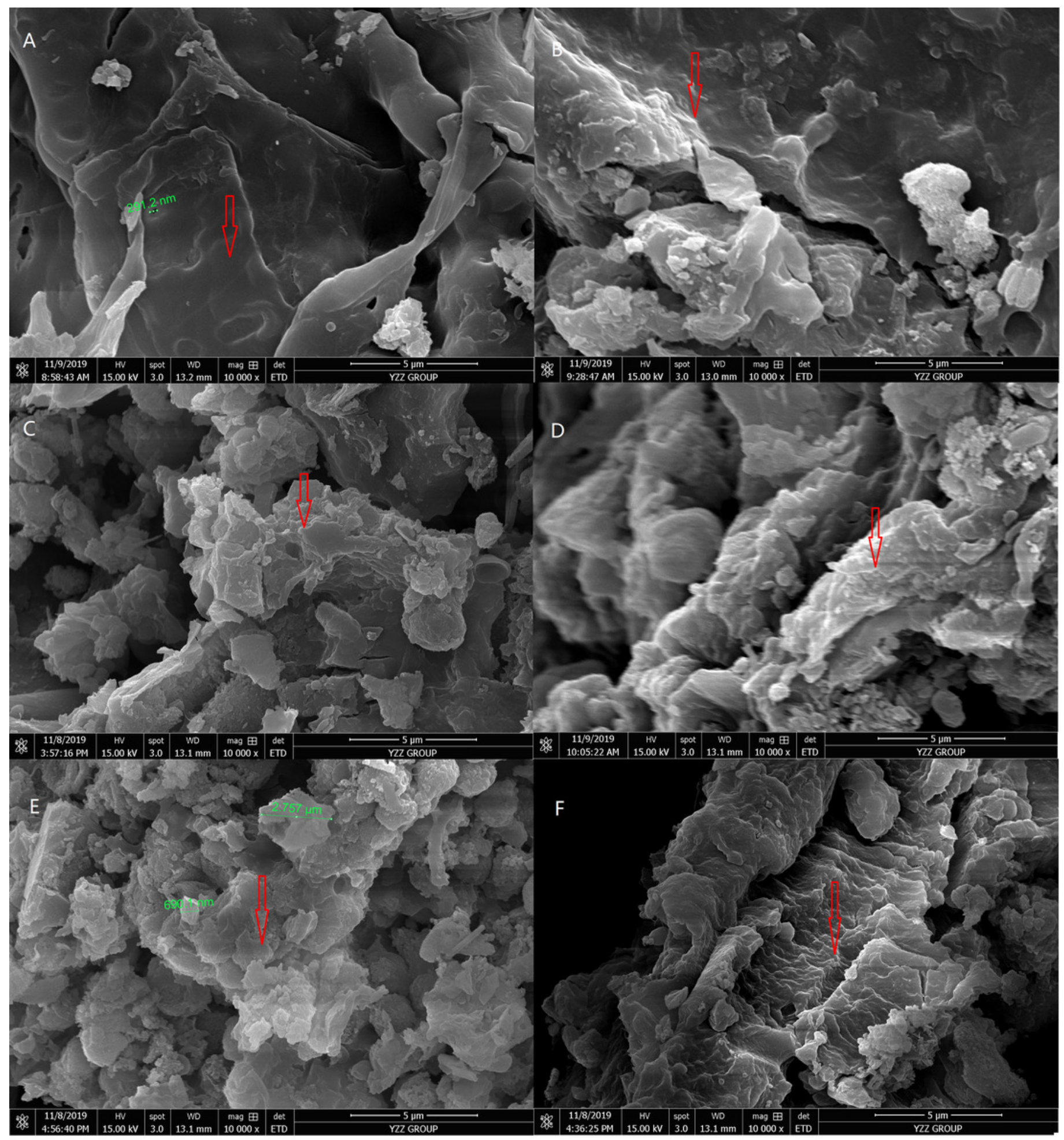


Figure 3

Figure 3. Contents of cellulose and lignin; degradation rate of cellulose and lignin; and the activities of cellulase and PPO in different treatments during 56 days of vermicomposting.

Figure 3. Contents of cellulose (A) and lignin (B); degradation rate of cellulose (C) and lignin (D); and the activities of cellulase (E) and PPO (F) in different treatments during 56 days of vermicomposting. Vertical bars in the figures represent standard error of the means $(n=3)$.
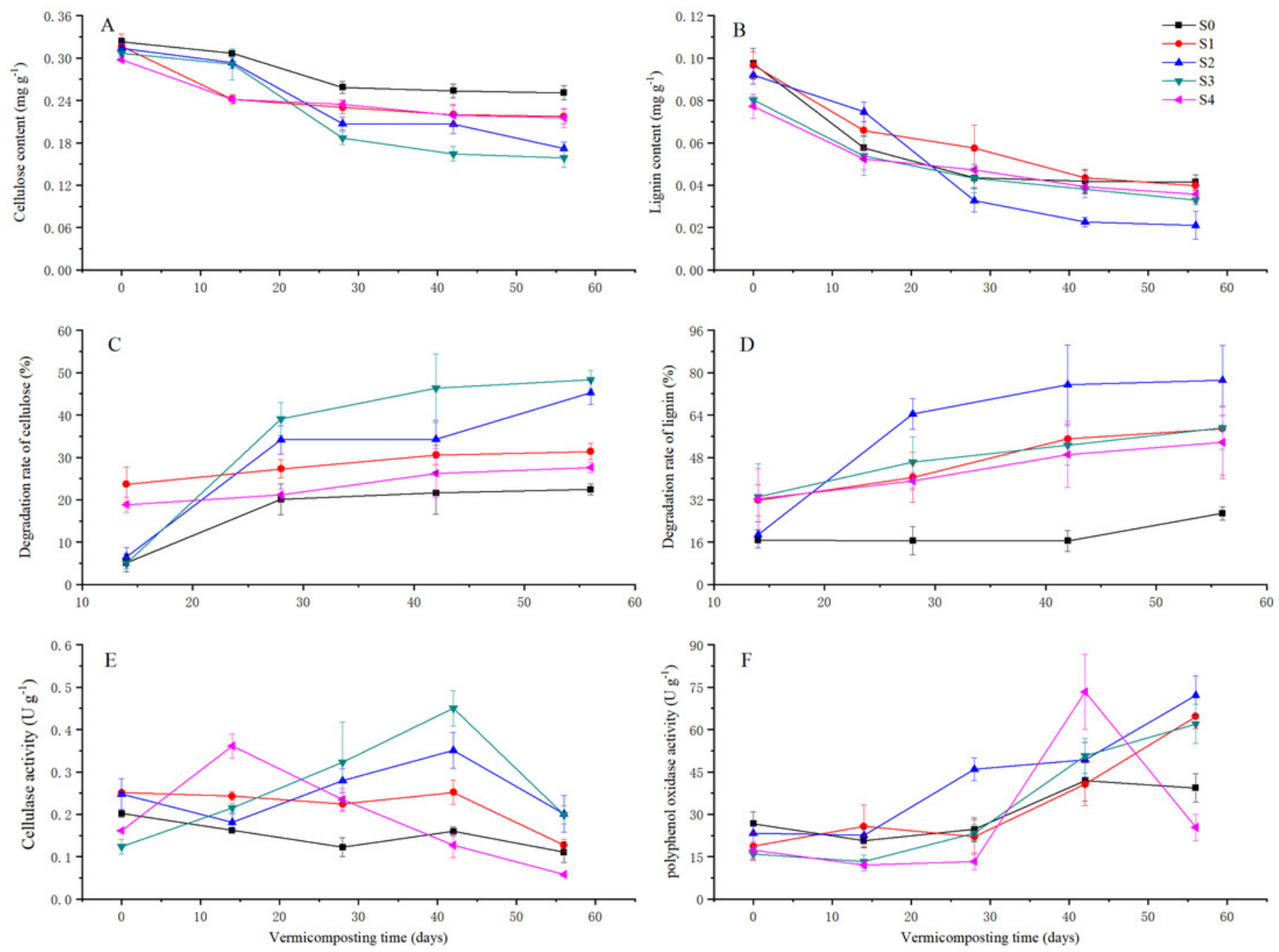
Figure 4

Figure 4. Germination Indexes (GI) of Zea mays linn. Spp. (\%).

Figure 4. Germination Indexes (GI) of Zea mays linn. Spp. (\%). 1.25\% extractions of SMS products in different treatments after 56 days of vermicomposting were used in this germination test. Vertical bars in the figures represent standard error of the means $(n=3)$.

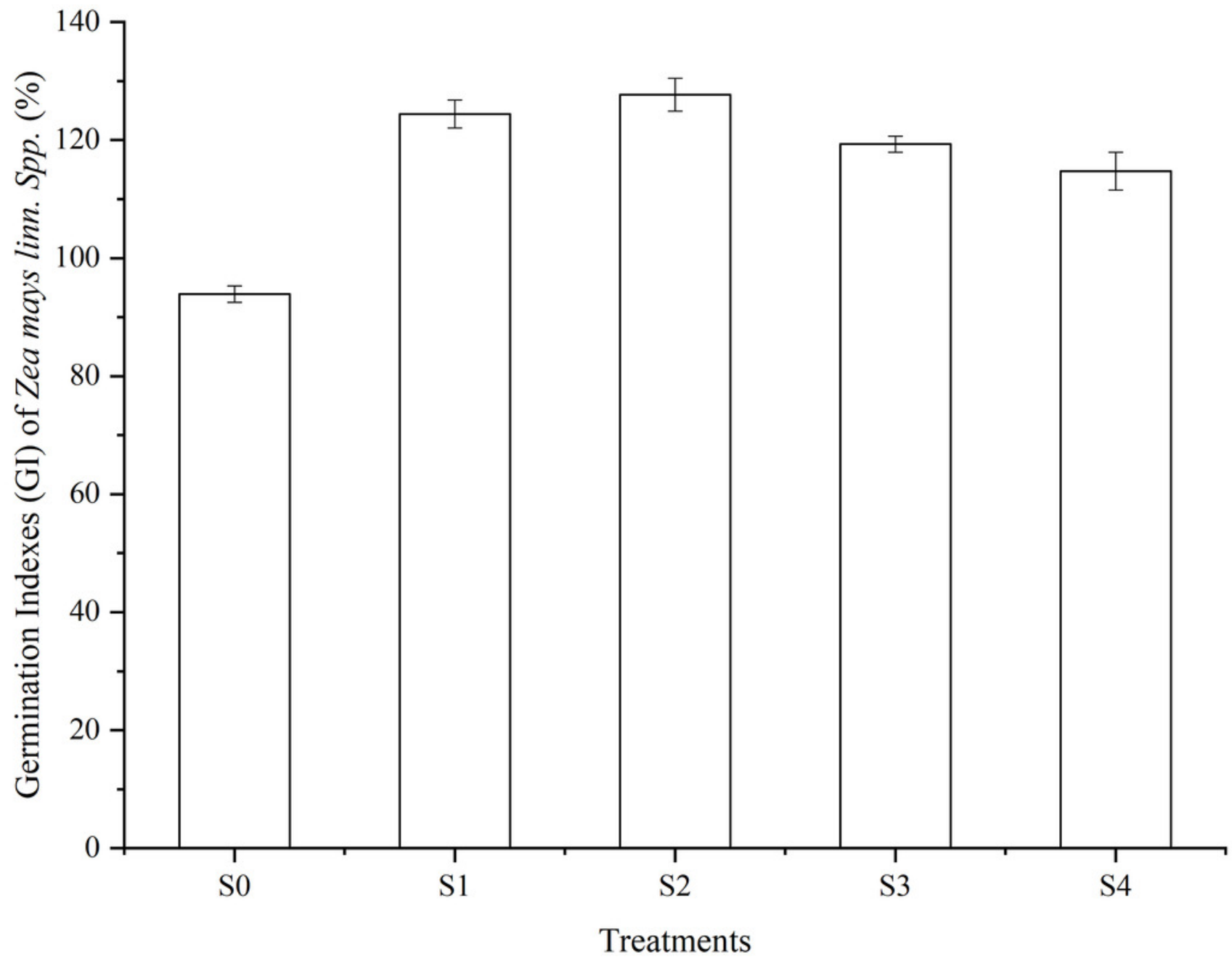

